\title{
Identification of Candida Species Isolated from Egyptians Patients with Chest Infection Using Integral System Yeast Plus
}

\section{Marwa Samy Gamel Taha*, Hanan Samir Abdel Khalik, Abdel RehemGharib Adds, Mohamed Ismaiel Abdel Hamid and Amgad Abdel Raouf Farahat}

Department of Microbiology, Faculty of Medicine, Tanta University, Egypt

*Corresponding author

\section{A B S T R A C T}

Pulmonary fungal infections are common potentially life-threatening conditions in immuno-compromised patients. Diagnosis represents a challenge due to the non-specific clinical manifestations. Empirical use of anti-fungal drug therapy has been a burden for

\section{Keywords}

Candida chest infection, Integral system yeasts plus

Article Info

Accepted:

16 December 2017

Available Online:

10 January 2018 years due to high cost and drug toxicity. This study was designed to determine the presence of Candida chest infection in immuno-compromised patients in Tanta University Hospitals. A total of 150 patients with chest infection were selected during the period from June 2015 till June 2017. Collected samples were cultured on Sabouraud's Dextrose agar media. Candida isolates were tested using integral system yeast plus (ISYP) for yeast typing and antifungal susceptibility. Out of 150 tested samples, candida was isolated from 44 samples. ISYP showed that The highest prevalence (36.4\%) was for Candida albicans, followed by Candida tropicalis (25\%), thirdly Candida parapsilosis (15.9\%), then Candida krusei (11.4\%), followed by Candida famata, Candida stellatoidea and Candida zylanooides with percentage as $(4.5,4.5$ and $2.3 \%)$ respectively. Each candida species has different antifungal sensitivity patterns. It is concluded that Candida albicans, Candida tropicalis and Candida parapsilosis were the predominant Candida species causing chest infections in immuno-compromised patients. Further studies must be done to test the sensitivity and accuracy of ISYP.

\section{Introduction}

Fungal chest infection is a serious lifethreatening infection with a $60-80 \%$ mortality rate in immuno-compromised children and adults (Hardak et al., 2009).

Candida albicans is the most frequent species isolated from respiratory samples (approx. $50 \%$ ) followed by C. parapsilosis, C. tropicalis and $C$. glabrata. Despite the frequent isolation of Candida spp. from respiratory samples, isolation in nonneutropenic patients is not considered as a diagnostic method of pneumonia regardless the species isolated (Garnacho-Montero et al., 2013).

The diagnosis of fungal chest infection is challenging due to a lack of sensitive and specific clinical and radiological signs, and tissue biopsy is often precluded (and 
invasive), especially among patients with thrombocytopenia (Torelli et al., 2011). The traditional microbiological workup of clinical specimens is based on microscopic examination and culture on mycological media (Lass-Flörl et al., 2013).

No method has proven to be sufficiently sensitive and specific to allow adequate diagnosis, and the "gold standard" consists of microscopy and culture (Pound et al., 2010). Microscopic examination allows the cheap and rapid detection of fungal elements in clinical specimens. Despite this advantage of providing an early presumptive or definitive diagnosis of invasive fungal infection (IFI), fungal classification is not possible (Penack $e t$ al., 2008).

In order to identify isolated yeast species, appearance and configuration of the colonies and germ tube test are used, in addition to these conventional methods, commercial kits which provided quick identification and antifungal susceptibility are used (Baran et al., 2013).

The aim of the present study was to determine the presence of Candida chest infection in immuno-compromised patients and pneumonic patients in Tanta University Hospitals by Culture. Then we used INTEGRAL SYSTEM YEASTS Plus Test for yeast typing and antifungal susceptibility.

\section{Materials and Methods}

\section{Study design and participants}

This prospective study was carried out in the Medical Microbiology and Immunology Department, Faculty of Medicine, Tanta University during the period from June 2015 till June 2017 on 150 patients selected from Intensive Care Units (ICUs), Chest department and Oncology department of Tanta University Hospitals.
All patients were immuno-compromised (males and females) suffering from symptoms of chest infection and pneumonia. Demographic variables such as gender, age, underlying disease together with the patients' clinical data, degree of critical illness, risk factors of pneumonia, length of ICU stay, and antibiotic regimen were collected from patients' records.

Patients in this study were subjected to complete medical history with particular emphasis on the age, underlying disease, time of onset of pneumonia and through clinical examination to diagnose chest disease.

\section{Collection of samples and microbiological examination}

\section{Clinical specimens}

\section{Sputum}

Fifty sputum samples were collected from Immuno-compromised patients with chest infection having expectoration, first early morning sputum samples were collected in sterile screw capped plastic container after instruction to patient to brush his teeth and rinse mouth with water, sputum should be as a result of deep cough (not saliva).

\section{Bronchoalvolar lavage (BAL)}

Fifty BAL samples were obtained from patients with chest-x-ray abnormalities complaining from unresolved pneumonia, collected aseptically in sterile screw capped plastic container, and immediately transported to the laboratory, the fluid was processed for culture and direct microscopic examination.

\section{Endotracheal aspirate}

Fifty Endotracheal aspirate samples were collected from ventilated patients suffering from ventilator associated pneumonia (VAP), 
collected aseptically and immediately transported to the laboratory, the fluid was processed for culture and direct microscopic examination.

All collected samples were cultured on Sabouraud's Dextrose agar media. Identification of fungus species by Colony morphology, Gram stain and Germ tube test.

\section{Integral System Yeasts Plus}

Was used for yeast typing and antifungal susceptibility: which is a 24 wells system containing biochemical substrata and dried antimycotics for the identification of the most clinically important yeasts and sensitivity evaluation to antimycotics. The system is inoculated with the cell suspension and incubated at $36 \pm 1^{\circ} \mathrm{C}$ for 48 hours.

Presumptive Identification is based on assimilation reactions of sugars; the tests for the assimilation reactions are interpreted by evaluating the color change of wells 1-GLU to 12-DUL. The combination of positive and negative reactions allows the formation of a numerical code which permits to identify the yeasts under examination, through the use of the table of codes.

The well 13-CHR contains a chromogenic substrate that permits to differentiate some yeast by evaluating the color change of the well.

Sensitivity to antimycotics, the tests are evaluated according to growth or inhibition of yeasts in media containing the antimycotic and a growth indicator in the wells 14-NY to 23FLU.

The color change from red to orange in the wells indicates a slow growth of the yeast under examination and an intermediate sensitivity to the concentration of antimycotic in the well. The color change from red to yellow in the wells indicates a growth of the yeast under examination and resistance to the concentration of antimycotic in the well.

No color change in the well indicates no growth of the yeast under examination and sensitivity to the concentration of antimycotic in the well.

The well 24-Growth does not contain antimycotics, it contains culture medium and indicator and it works as growth control.

\section{Statistical analysis}

Data were fed to computer and analyzed using IBM SPSS software package version 20.0. (Armonk, NY: IBM Corp).Qualitative data were described using number and percent. Significance of the obtained results was judged at the $5 \%$ level.

\section{The tests used were}

\section{Chi-square test}

For categorical variables, to compare between different groups.

\section{Fisher's Exact}

Correction for chi-square when more than $20 \%$ of the cells have expected count less than 5.

\section{Ethical approval}

The study protocol was reviewed and approved by the local ethical committee of Faculty of Medicine, Tanta University, Egypt.

\section{Results and Discussion}

This work was carried out on 150 immunocompromised patients [males $(n=82)$ and 
females $(n=68)]$ suffering from symptoms of chest infection and pneumonia, selected from Intensive Care Units, Chest department and Oncology department (50 cases of each respectively) of Tanta University Hospitals during the period from June 2015 till June 2017.

Among 150 clinically suspected cases, Candida infection was detected in 44 cases (29.3\%). The highest prevalence (36.4) was for Candida albicans, the second percentage was $25 \%$ for Candida tropicalis, the third one (15.9\%) was for Candida parapsilosis, the fourth was (11.4\%) for Candida krusei, followed by Candida famata, Candida stellatoidea and Candida zylanooides with percentage as $(4.5,4.5$ and $2.3 \%)$ respectively (Table 1).

Table 2 shows Sensitivity and Accuracy for chrom method which was (59.09 for both) Antibiogram of Candida albicans (16 cases) reveal that the pathogens are more sensitive to Flucytosine $16 \mu \mathrm{g} / \mathrm{mL}$ (13cases) followed by Ketoconazole $0.5 \mu \mathrm{g} / \mathrm{mL}$ and Fluconazole 64 $\mu \mathrm{g} / \mathrm{mL}$ (6 cases for each) while the highest resistance was for Clotrimazole $1 \mu \mathrm{g} / \mathrm{mL}$ (11 cases followed by Econazole $2 \mu \mathrm{g} / \mathrm{mL}$ (7 cases) (Fig. 1).

Antibiogram of Candida tropicalis (11 cases) reveal that the pathogens are more sensitive to Flucytosine $16 \mu \mathrm{g} / \mathrm{mL}$ (7 cases) while the highest resistance was for Clotrimazole $\mu \mathrm{g} / \mathrm{mL}$ (11 cases) (Fig. 2).

Antibiogram of Candida parapsilosis (7 cases) reveal that the pathogens are more sensitive to Flucytosine $16 \mu \mathrm{g} / \mathrm{mL}$ ( 7 cases) while the only resistance was for Miconazole $\mu \mathrm{g} / \mathrm{mL}$ (4 cases) (Fig. 3).

Antibiogram of Candida krusei (5 cases) reveal that the pathogens are only sensitive to Flucytosine $16 \mu \mathrm{g} / \mathrm{mL}$, Ketoconazole 0.5 $\mu \mathrm{g} / \mathrm{mL}$ and Voriconazole $2 \mu \mathrm{g} / \mathrm{mL}$ ( 3 cases for each) while the highest resistance was for Nystatin $1.25 \mu \mathrm{g} / \mathrm{mL}$, Amphotericin $2 \mu \mathrm{g} / \mathrm{mL}$, Econazole $2 \mu \mathrm{g} / \mathrm{mL}$, Clotrimazole $1 \mu \mathrm{g} / \mathrm{mL}$, Miconazole $2 \mu \mathrm{g} / \mathrm{mL}$, Itraconazole $1 \mu \mathrm{g} / \mathrm{mL}$ and Fluconazole $64 \mu \mathrm{g} / \mathrm{mL} \quad(5$ cases respectively (Fig. 4).

Antibiogram shows that Candida famata was sensitive to Nystatin $1.25 \mu \mathrm{g} / \mathrm{mL}$, Flucytosine $16 \mu \mathrm{g} / \mathrm{mL}$ and Ketoconazole $0.5 \mu \mathrm{g} / \mathrm{mL}(2$ cases respectively) while the pathogen shows resistance to Econazole $2 \mu \mathrm{g} / \mathrm{mL}$ and Clotrimazole $1 \mu \mathrm{g} / \mathrm{mL}$ ( 2 cases respectively).

Antibiogram of Candida stellatoidea (2 cases) reveal that the pathogens are only sensitive to Flucytosine $16 \mu \mathrm{g} / \mathrm{mL}$ and Nystatin 1.25 $\mu \mathrm{g} / \mathrm{mL}$ (2and 1 cases respectively) while the only resistance was for Clotrimazole $1 \mu \mathrm{g} / \mathrm{mL}$, (2cases).

Antibiogram of Candida zylanooides (1 case) reveal that the pathogen was sensitive to Flucytosine $16 \mu \mathrm{g} / \mathrm{mL}$, Nystatin $1.25 \mu \mathrm{g} / \mathrm{mL}$ and Econazole $2 \mu \mathrm{g} / \mathrm{mL}$ (1 case respectively) while the pathogen shows no resistance. The present study revealed that among 150 cases: Candida infection was detected in 44 cases (29.3\%)

In accordance with our result, a study conducted in India by Gupta et al., 2016 estimated that from 210 ICU patients, $52(24.7 \%)$ were fungal pathogens, Majority of the fungal pathogens were Candida species $42(82.3 \%)$.

The figure was different with Chakma et al., 2017 who reported that among 151 sputum samples Candida was isolated in $15.23 \%$ (23/151) samples. Also Yazıcıŏlu Moçin et al., 2013 reported that, among the 95 case patients, the microbiology results of 63 $(66.3 \%)$ revealed fungi $(90.5 \%$ Candida species; $9.5 \%$ Aspergillus). 
Table.1 Distribution of Candida species among Candida cases detected $(\mathrm{n}=44)$

\begin{tabular}{|l|c|c|}
\hline \multicolumn{1}{|c|}{ Types of Candida } & No. & $\%$ \\
\hline Candida albicans & & \\
\hline Candida tropicalis & 16 & 36.4 \\
\hline Candida parapsilosis & 11 & 25.0 \\
\hline Candida krusei & 7 & 15.9 \\
\hline Candida farmata & 5 & 11.4 \\
\hline Candida stellatoidea & 2 & 4.5 \\
\hline Candida zylanooides & 2 & 4.5 \\
\hline
\end{tabular}

The highest prevalence (36.4) was for Candida albicans, the second percentage was $25 \%$ for Candida tropicalis, the third one (15.9\%) was for Candida parapsilosis, the fourth was (11.4\%) for Candida krusei, followed by Candida famata, Candida stellatoidea and Candida zylanooides with percentage as (4.5, 4.5 and 2.3\%) respectively.

Table.2 Agreement for Chrom substrate result

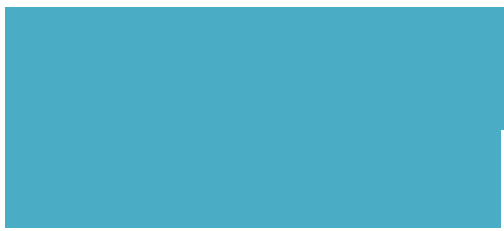

Chrom substrate result

\section{Negative Positive}

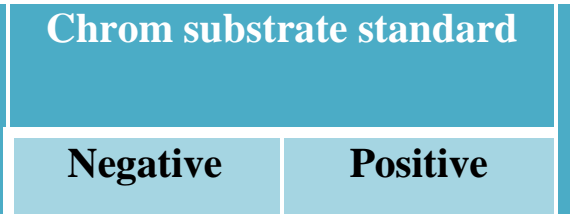

18

26
0

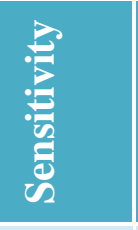

59.09
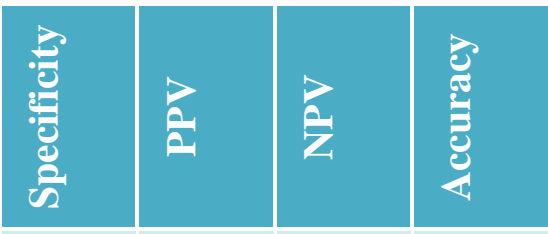

$-100.0$

This table shows Sensitivity and Accuracy for chrom method which was (59.09 for both)

Fig.1 Antibiogram of Candida albicans Cases $(\mathrm{n}=16)$

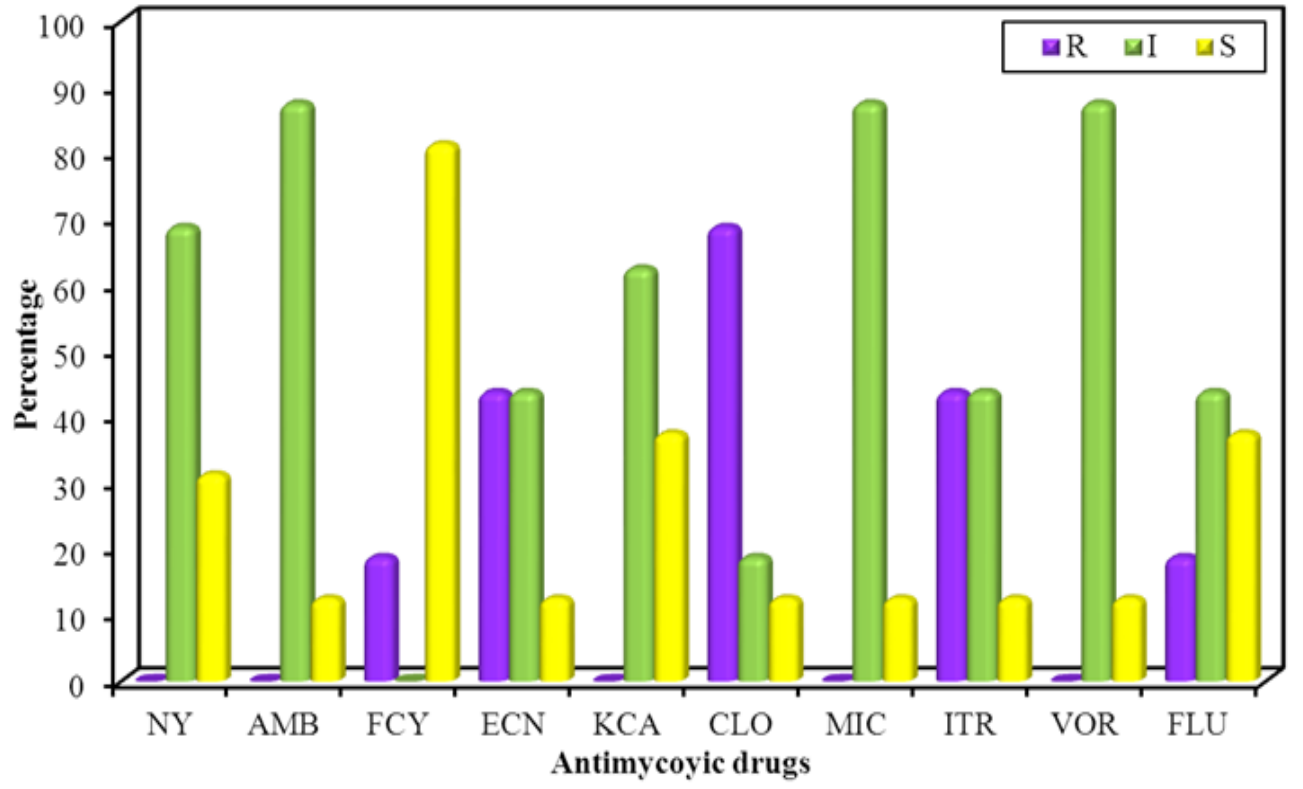

Antibiogram of Candida albicans (16 cases) reveal that the pathogens are more sensitive to Flucytosine $16 \mu \mathrm{g} / \mathrm{mL}$ (13cases) followed by Ketoconazole $0.5 \mu \mathrm{g} / \mathrm{mL}$ and Fluconazole $64 \mu \mathrm{g} / \mathrm{mL}$ ( 6 cases for each) while the highest resistance was for Clotrimazole $1 \mu \mathrm{g} / \mathrm{mL}$ ( 11 cases followed by Econazole $2 \mu \mathrm{g} / \mathrm{mL}$ ( 7 cases). 
Fig.2 Antibiogram of Candida tropicalis cases $(\mathrm{n}=11)$

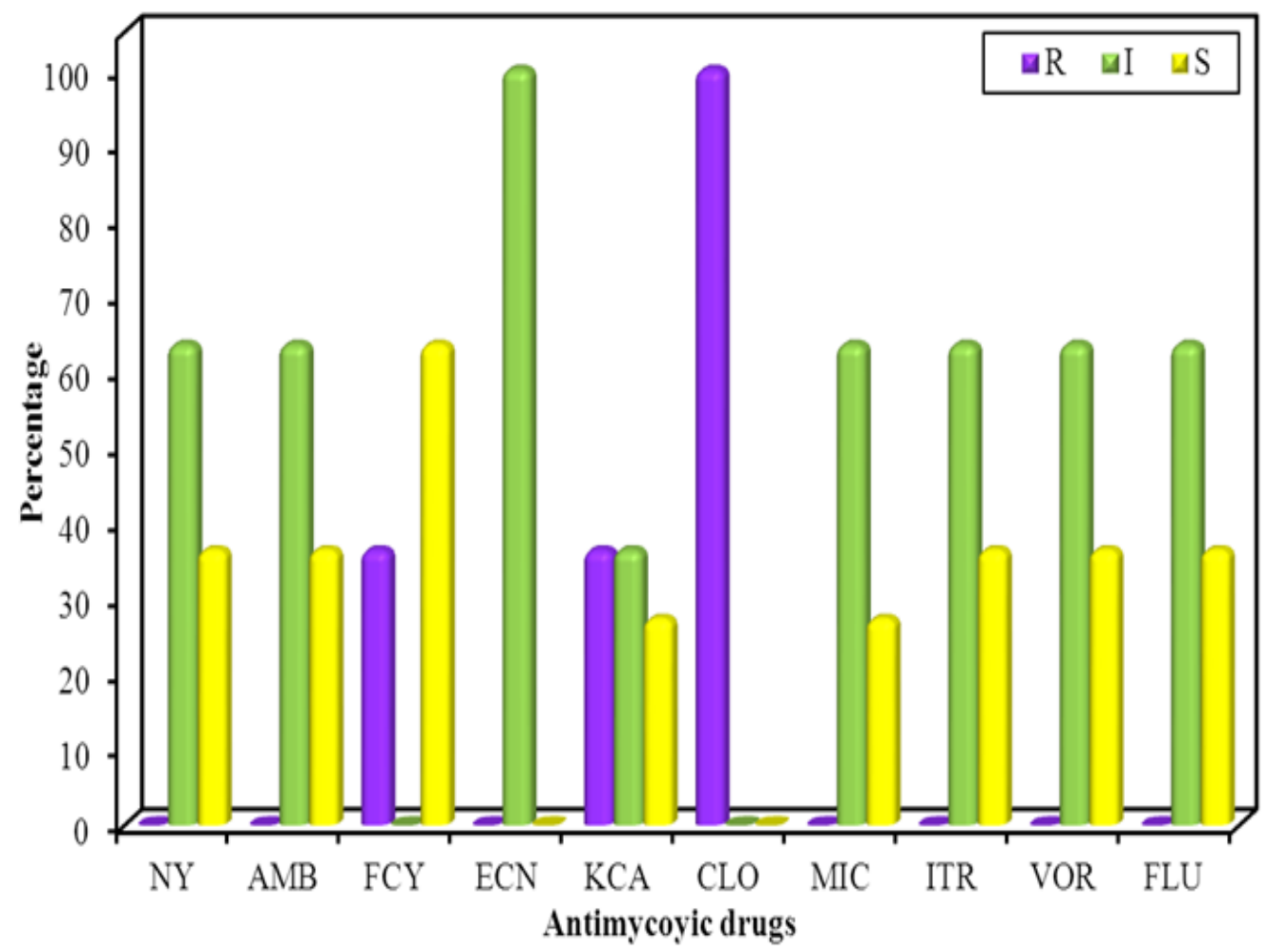

Antibiogram of Candida tropicalis (11 cases) reveal that the pathogens are more sensitive to Flucytosine $16 \mu \mathrm{g} / \mathrm{mL}$ ( 7 cases) while the highest resistance was for Clotrimazole $\mu \mathrm{g} / \mathrm{mL}$ (11 cases).

Fig.3 Antibiogram of Candida parapsilosis cases $(n=7)$

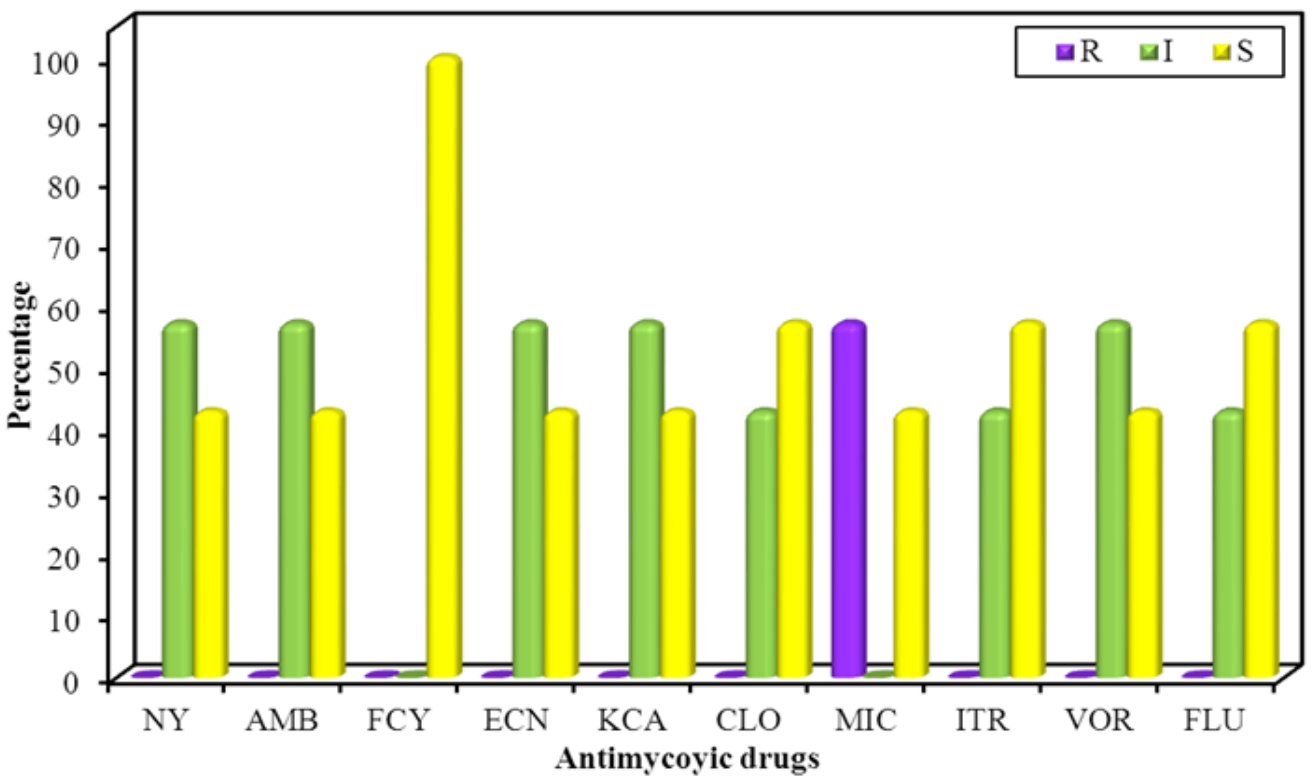

Antibiogram of Candida parapsilosis ( 7 cases) reveal that the pathogens are more sensitive to Flucytosine $16 \mu \mathrm{g} / \mathrm{mL}$ ( 7 cases) while the only resistance was for Miconazole $\mu \mathrm{g} / \mathrm{mL}$ ( 4 cases). 
Fig.4 Antibiogram of Candida krusei cases ( $\mathrm{n}=5)$

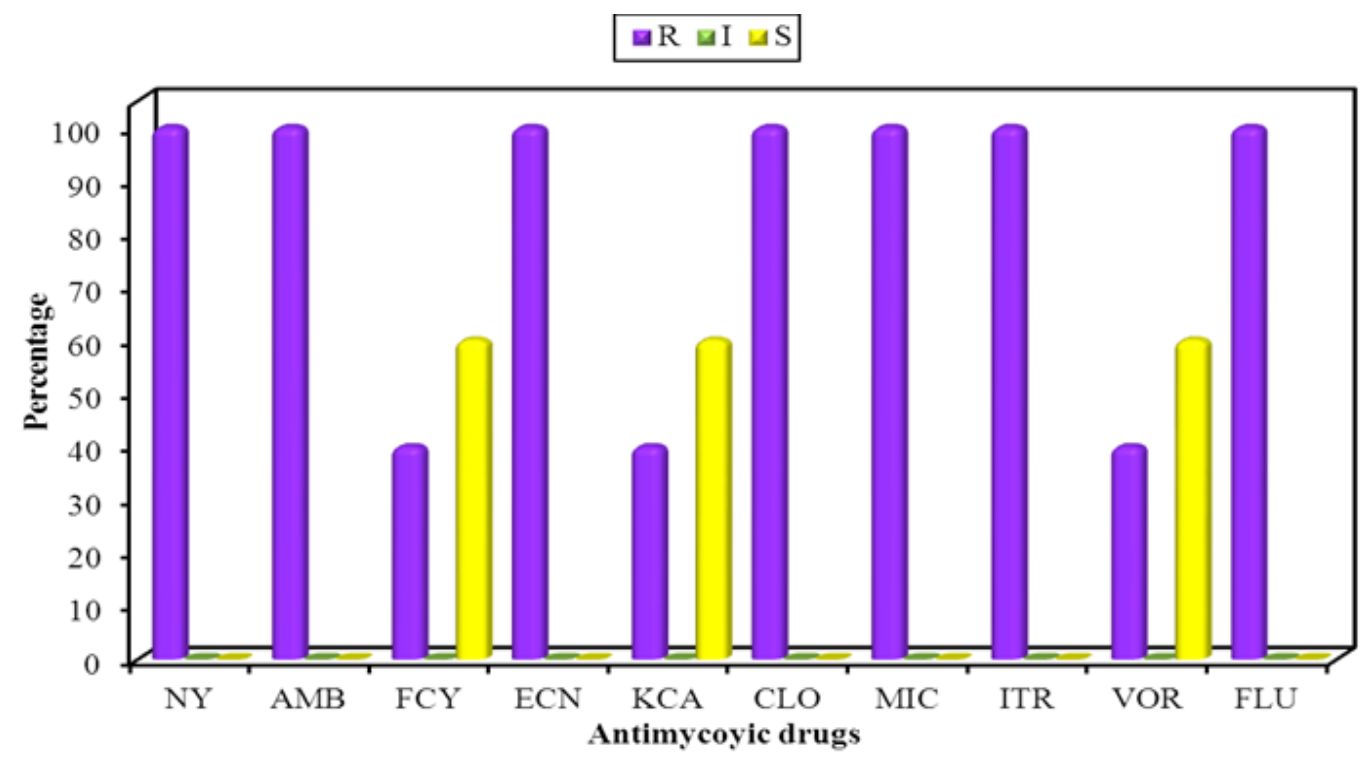

Antibiogram of Candida krusei (5 cases) reveal that the pathogens are only sensitive to Flucytosine $16 \mu \mathrm{g} / \mathrm{mL}$, Ketoconazole $0.5 \mu \mathrm{g} / \mathrm{mL}$ and Voriconazole $2 \mu \mathrm{g} / \mathrm{mL}$ ( 3 cases for each) while the highest resistance was for Nystatin $1.25 \mu \mathrm{g} / \mathrm{mL}$, Amphotericin $2 \mu \mathrm{g} / \mathrm{mL}$, Econazole $2 \mu \mathrm{g} / \mathrm{mL}$, Clotrimazole $1 \mu \mathrm{g} / \mathrm{mL}$, Miconazole $2 \mu \mathrm{g} / \mathrm{mL}$, Itraconazole $1 \mu \mathrm{g} / \mathrm{mL}$ and Fluconazole $64 \mu \mathrm{g} / \mathrm{mL}$ ( 5 cases respectively).

Our study use CHROM substrate Candida as a method of typing of Candida which Sensitivity was (59.09) and positive predictive value (PPV) was $100 \%$.

Against our result, Ozcan et al., (2010) who reported that Sensitivity of chrom agar Candida was 87.5 and positive predictive value (PPV) was $100 \%$.

Also Peng et al., 2007 reported that the sensitivity and specificity for CHROM substrate Candida in C. albicans identification were $100 \%$ and $94.6 \%$ respectively.

Regarding antibiogram of Candida albicans (16 cases) reveal that pathogens are more sensitive to Flucytosine $16 \mu \mathrm{g} / \mathrm{mL}$ (13cases) followed by Ketoconazole $0.5 \mu \mathrm{g} / \mathrm{mL}$ and Fluconazole 64 $\mu \mathrm{g} / \mathrm{mL}$ (6 cases for each) while the highest resistance was for Clotrimazole $1 \mu \mathrm{g} / \mathrm{mL}$ (11 cases followed by Econazole $2 \mu \mathrm{g} / \mathrm{mL}$ ( 7 cases). According to the study of Njunda et al., (2013), C. albicans isolated reported high susceptibility to ketoconazole $(80.2 \%)$ which is in agreement with our study while they stated that Nystatin was the least susceptible antifungal drug to Candida albicans which is against our study which shows lowest sensitivity to Econazole.

Although, Francuzik et al., (2015) reported that C. albicans strains were the most resistant against antimycotics. On the other hand Gupta et al., (2016) found that 11(34.3\%) and $7(21.8 \%)$ of C. albicans were resistant to fluconazole and nystatin respectively.

Regarding antibiogram of Candida tropicalis (11 cases) which reveal that the pathogens are more sensitive to Flucytosine $16 \mu \mathrm{g} / \mathrm{mL}$ (7 cases) while the highest resistance was for Clotrimazole $\mu \mathrm{g} / \mathrm{mL}$ (11 cases) but it is nearly comparable to that reported by Njunda et al., (2013) who stated that Candida tropical is recorded high susceptibility to ketoconazole $(94.7 \%)$ followed by voriconazole $(78.9 \%)$ and miconazole (73.7\%). Nystatin was least resistant. Antibiogram of Candida parapsilosis ( 7 cases) reveal that the pathogens are more sensitive to Flucytosine $16 \mu \mathrm{g} / \mathrm{mL}$ ( 7 cases) while the only resistance was for Miconazole $\mu \mathrm{g} / \mathrm{mL}$ (4 cases). These results differed from 
that of Njunda et al., 2013 who reported that Candida parapsilosis recorded $100 \%$ susceptibility to all 10 antifungal agents

Regarding antibiogram of Candida krusei (5 cases) reveal that the pathogens are only sensitive to Flucytosine $16 \mu \mathrm{g} / \mathrm{mL}$, Ketoconazole $0.5 \mu \mathrm{g} / \mathrm{mL}$ and Voriconazole 2 $\mu \mathrm{g} / \mathrm{mL}$ (3 cases for each) while the highest resistance was for Nystatin $1.25 \mu \mathrm{g} / \mathrm{mL}$, Amphotericin $2 \mu \mathrm{g} / \mathrm{mL}$, Econazole $2 \mu \mathrm{g} / \mathrm{mL}$, Clotrimazole $1 \mu \mathrm{g} / \mathrm{mL}$, Miconazole $2 \mu \mathrm{g} / \mathrm{mL}$, Itraconazole $1 \mu \mathrm{g} / \mathrm{mL}$ and Fluconazole 64 $\mu \mathrm{g} / \mathrm{mL}$ (5 cases respectively).

This was in agreement with Pfaller et al., 2008 who found that C. krusei exhibited decreased susceptibility to voriconazole $(82.9 \% \mathrm{~S}, 7.8 \%$ R) also Francuzik et al., (2015) found that all isolated C. krusei is resistant to Fluconazole.

On the other hand Njunda et al., (2013) reported that Candida krusei which were isolated exclusively from the oral cavity recorded $100 \%$ susceptibility to all 10 antifungal agents.

Antibiogram shows that Candida famata was sensitive to Nystatin $1.25 \mu \mathrm{g} / \mathrm{mL}$, Flucytosine $16 \mu \mathrm{g} / \mathrm{mL}$ and Ketoconazole $0.5 \mu \mathrm{g} / \mathrm{mL}$ ( 2 cases respectively) while the pathogen shows resistance to Econazole $2 \mu \mathrm{g} / \mathrm{mL}$ and Clotrimazole $1 \mu \mathrm{g} / \mathrm{mL}$ ( 2 cases respectively). Controversially, this result disagreed with Njunda et al., (2013) who found that the four Candida famata isolates exhibited $100 \%$ susceptibility to ketoconazole, amphotericin B and fluconazole. Resistance was recorded with nystatin (50\%) and flucytosine (25\%).

Antibiogram of Candida zylanooides (1 case) reveal that the pathogen was sensitive to Flucytosine $16 \mu \mathrm{g} / \mathrm{mL}$, Nystatin $1.25 \mu \mathrm{g} / \mathrm{mL}$ and Econazole $2 \mu \mathrm{g} / \mathrm{mL}$ (1 case respectively) while the pathogen shows no resistance. This is in agreement with Njunda et al., 2013 who found that Candida zeylanoides, which were isolated exclusively from the oral cavity, recorded $100 \%$ susceptibility to all 10 antifungal agents
Comparison between C. albicans and Candida non albicans to different antifungal agents showed that resistance to clotrimoxazole was significantly detected in Candida non albicans isolates compared to C. albicans isolates (Francuzik et al., 2015).

In conclusion, Studies that determine the incidence of fungal infections in all departments of our hospital should repeatedly be performed in order to stand the magnitude of the problem.

Also Fungal cultures and antifungal susceptibility testing for all suspected cases of fungal chest infection or pneumonia should be performed to confirm the etiology and administer the proper treatment to reduce the morbidity and mortality rate.

Establishment of antifungals treatment protocols to avoid overuse and misuse of antifungals drugs to prevent the emergence of resistant fungal strains especially in hospital environment.

Further studies must be done to prove importance of Integral System Yeasts Plus for yeast typing and antifungal susceptibility and also to test the sensitivity and accuracy of it

\section{References}

Baran, N., Salman, I. S., Yurtsever, S. G., Ozdemir, R., Gungor, S., Yurtsever, S., and Demirci, M. 2013. Typing of Candida species isolated from blood cultures and analysis of their in vitro antifungal susceptibilities. African Journal of Microbiology Research, 7(41), 4882-4885.

Chakma S, Majumdar T, Singh NGB. Study of opportunistic pathogens in lower respiratory tract infections among subjects with acquired immune deficiency syndrome (AIDS) in a tertiary care centre of Tripura. J. Evolution Med. Dent. Sci. 2017; 6(31): 2523-2527, DOI: $10.14260 / J e m d s /$ $2017 / 546$

Francuzik, W., Skłodowska, A., Adamska, K., Adamski, Z., Tamowicz, B., and Mikstacki, 
A. 2015. Prevalence of yeast fungal infections in intensive care unit in Poland (No. e785v1). PeerJPrePrints.

Garnacho-Montero, J., Olaechea, P., AlvarezLerma, F., Alvarez-Rocha, L., Blanquer, J., Galván, B. and Solé, A. M. P. A. R. O. 2013.Epidemiology, diagnosis and treatment of fungal respiratory infections in the critically ill patient. Rev EspQuimioter, 26(2), 173-188.

Gupta, R., Malik, A., Rizvi, M., and Ahmed, M. 2016. An Alarming Increase of Fungal Infections in Intensive Care Unit: Challenges in the Diagnosis and Treatment. Journal of Applied Pharmaceutical Science Vol, 6(11), 114-119.

Hardak, E., Yigla, M., Avivi, I., Fruchter, O., Sprecher, H., and Oren, I. 2009.Impact of PCR-based diagnosis of invasive pulmonary aspergillosis on clinical outcome. Bone marrow transplantation, 44(9), 595.

Lass-Flörl, C., Mutschlechner, W., Aigner, M., Grif, K., Marth, C., Girschikofsky, M., and Eller, M. 2013. Utility of PCR in diagnosis of invasive fungal infections: real-life data from a multicenter study. Journal of clinical microbiology, 51(3), 863-868

Njunda, L. A., Assob, J. C., Nsagha, S. D., Kamga, H. L., Ndellejong, E. C., and Kwenti, T. E. 2013. Oral and urinary colonisation of Candida species in HIV/AIDS patients in Cameroon. Basic Sciences of Medicine, 2(1), 1-8.

Ozcan, K., Ilkit, M., Ates, A., Turac-Bicer, A., and Demirhindi, H. 2010.Performance of Chromogenic Candida agar and CHROMagar Candida in recovery and presumptive identification of monofungal and polyfungal vaginal isolates. Medical mycology, 48(1), 29-34.

Penack, O., Rempf, P., Graf, B., Blau, I. W., and
Thiel, E. 2008. Aspergillus galactomannan testing in patients with long-term neutropenia: implications for clinical management. Annals of Oncology, 19(5), 984-989.

Peng, C. F., Lee, K. M., and Lee, S. H. 2007. Characterization of two chromogenic media of Candida ID2 and CHROMagar Candida for preliminary identification of yeasts. $J$ Biomed Lab Sci, 19(2), 63-68.

Pfaller, M. A., Diekema, D. J., Gibbs, D. L., Newell, V. A., Nagy, E., Dobiasova, S., and Global Antifungal Surveillance Group. 2008. Candida krusei, a multidrug-resistant opportunistic fungal pathogen: geographic and temporal trends from the ARTEMIS DISK Antifungal Surveillance Program, 2001 to 2005. Journal of clinical microbiology, 46(2), 515-521.

Pound, M. W., Townsend, M. L., and Drew, R. H. 2010. Echinocandin pharmaco dynamics: review and clinical implications. Journal of Antimicrobial Chemotherapy, 65(6), 11081118.

Torelli, R., Sanguinetti, M., Moody, A., Pagano, L., Caira, M., De Carolis, E., and Fadda, G. 2011. Diagnosis of invasive aspergillosis by a commercial real-time PCR assay for Aspergillus DNA in bronchoalveolar lavage fluid samples from high-risk patients compared to a galactomannan enzyme immunoassay. Journal of clinical microbiology, 49(12), 4273-4278.

YazıcıoğluMoçin, Ö, Karakurt, Z., Aksoy, F., Güngör, G., Partal, M., Adigüzel, N., and Erdem, H. 2013. Bronchoscopy as an indicator of tracheobronchial fungal infection in non-neutropenic intensive-care unit patients. Clinical Microbiology and Infection, 19(3), 136141.

\section{How to cite this article:}

Marwa Samy Gamel Taha, Hanan Samir Abdel Khalik, Abdel RehemGharib Adds, Mohamed Ismaiel Abdel Hamid and Amgad Abdel Raouf Farahat. 2018. Identification of Candida Species Isolated from Egyptians Patients with Chest Infection Using Integral System Yeast Plus. Int.J.Curr.Microbiol.App.Sci. 7(01): 2327-2335. doi: https://doi.org/10.20546/ijcmas.2018.701.281 